\title{
CePiS, a great opportunity for innovation in health.
}

\section{Juan Cartes-Velásquez. ${ }^{1}$}

In recent years, in Chile and the world, innovation and entrepreneurship ecosystems have proven to be a great contribution to the development of humanity. These ecosystems are the cradle of ideas that solve problems or "relieve some of the pains" of our society. This is achieved through the continuous improvement of the state of the art of products and services, generation of new job opportunities, as well as the promotion and revitalization of the economic progress of a country. Therefore, it is necessary to continue fostering the policies that support startups that dare to innovate. These policies must include financial support, mentoring, access to work spaces and the articulation of an ecosystem that brings clients and / or users and innovators closer together.

It is necessary to make clear that each area will present its own challenges, entry barriers, requirements, pains and / or work methodologies. Consequently, the tools that each startup needs to develop their product and / or service successfully can be similar, but never the same. For example, the requirements for development in the area of universal access and inclusion, such as Lazarillo, differ significantly from those related to the area of private urban transport, such as Uber; since these focus on market segments that differ in users, customers, facilitators, among others. This difference in tools is more noticeable in Health, since a new product and / or service should not only focus on improving the performance of a new machine, improving the traceability of an input, scalability in the patient care and reducing costs, but also on meeting quality standards, intrahospital interoperability, safety, precision, patient care, among others. We must not forget that a Health product and / or service can significantly influence the patient's experience and can even make the difference between life and death.

Technological innovation has played a fundamental role in the transformation of the health sector, from research and treatments, to data collection, paving the way for incredible changes in the healthcare industry. However, in my opinion, the main barriers to the development of technological alternatives arise within the health sector. Until now, there was no entity in charge of articulating and communicating innovators with healthcare providers, whether due to distrust, reluctance to change or any other reason. Thus, good ideas die in the initial stages because they do not have the necessary information to identify specific requirements, validate the technical operation of a prototype or improve its value proposal. In addition, resources are allocated for the development of projects that are not technically feasible, their impact is not significant or they do not really solve a real problem. These situations show that collaborative work between hospitals and startups, access to information
Affiliation: ${ }^{1}$ Mitseyn Technologies. Concepción, Chile.

Corresponding author: Juan Cartes Velásquez. Beltrán Mathieu 143-A, oficina 2. Phone: +56971003862 . Email: juan@mitseyn.com.

Conflict of interests: None.

Acknowledgements: None.

doi: $10.32457 /$ ijmss.2018.022. 
and pilot spaces are as important as financial support or mentoring.

For this reason, the implementation of the Centers for Health Piloting (Centros de Pilotaje en Salud, CePiS) represents a great opportunity for every entrepreneur or startup linked to the health sector (Ministerio de Salud, 2018). The CePiS will allow validating hypotheses, performing tests and implementing the solutions that each team has in mind through an acceleration methodology, under a specific segmentation, according to public and private market requirements.

Finally, through mechanisms such as CePiS, the development of new technologies, products and services in the health sector will be encouraged. This will generate positive consequences in the ecosystem of innovation, in the sophistication of the solutions and revitalization of the economy, but even more important, it will improve the people's quality of life in a sustainable way.

\section{REFERENCES}

Ministerio de Salud. Ministerio de Salud y Corfo firman acuerdo que crea la primera aceleradora pública para emprendimientos tecnológicos en salud [Internet]. 2018. Available at: https://www.minsal.cl/ministerio-de-saludy-corfo-firman-acuerdo-que-crea-la-primera-aceleradorapublica-para-emprendimientos-tecnologicos-en-salud/.

Cartes-Velásquez J. CePiS, a great opportunity for innovation in health. Int J Med Surg Sci. 2018; 5(3): 91-92. 